\title{
IDENTIFYING THE MisconCEPTIONS OF NATURAL SCIENCE (IPA) USING CRI (CERTANTy OF RESPONSE INDEX) AT THE PRIMARY SCHOOL STUDENTS IN TARAKAN
}

\author{
Muhsinah Annisa ${ }^{1)}$, Ratna Yulinda ${ }^{2)}$, Kartini $^{3)}$ \\ 1, 2, 3) Universitas Borneo Tarakan \\ 1)E-mail:echa.ok@gmail.com
}

\begin{abstract}
The objective of this study is to identify the misconceptions of Natural Science (IPA) on primary school students in Tarakan. The output of this study is presented into a national scientific journal with ISSN. This study absolutely contributes to the schools and the education providers (universities). This study can identify the misconceptions of what happens to the students, so that teachers know how to handle and remediate these misconceptions. This study employs quantitative descriptive research. The population is the sixth grade students of primary schools in Tarakan. It is because the students of this grade have got the learning material on force, light, and simple machine. The technique.;s used in taking the sample is cluster sampling by considering on the three criteria, namely: superior, medium, and low school category which is based on the mean scores of final test (UAS) on natural science subject. So, the sixth grade students of SDN A, SDN B Tarakan, and SDN C Tarakan are chosen as the sample of this study. The instrument of this research is a written test in a form of multiple choice test equiped with the CRI (certainty of response index) answer sheet. The data are collected by distributing multiple-choice test which is consisted of 40 questions that are equipped with the CRI answer sheet.
\end{abstract}

Keywords: misconceptions, natural science, CRI, primary school.

\section{INTRODUCTION}

Education in Elementary School is a first place for students in imparting any basic knowledge that will be developed through teaching sector, and one of the subjects in elementary school is Natural Science (IPA). Natural science (IPA) is a science that studies every symptom through a series of processes that is known as scientific process and is constructed based on scientific attitude and the result is in a form of scientific product. The result is consisted of the most three important components namely concepts, principles, and theories that can be applied universally. Susanto (2013) stated that Learning Natural science in elementary school had many purposes, namely (1) to believe in the greatness of the Almighty God based on the existence of the beauty and the order of his creation; (2) to develop knowledge and understanding to the science concepts that are useful and can be applied in daily life; (3) to grow curiosity, positive attitudes and awareness on interplay relation between science, environment, technology, and society; (4) to develop the process skills to investigate the surrounding nature, to solve problems, and to decide; (5) to intensify the awareness in order to participate in preserving, maintaining, and conserving the natural environment; (6) to intensify the awareness to appreciate nature and all its regularity as one of God's creations, and (7) to acquire knowledge, concepts and skills on Natural Science as a basis for continuing education to junior high school [1].

Natural Science contains many concepts related to daily life; therefore it is crucial for students to understand any subjects on Natural Science. However, the facts show that a lot of students experience difficulties to understand the concepts in science subjects, for example: there are students who think that sun moves around the earth because they see the sun rise from east and go to west (sunset). This poor understanding is evidenced from interview results with students on September 16, 2016 by one of the classroom teachers in elementary school in Tarakan. The result shows that the teachers experienced difficulties on Natural Science learning because of student's poor understanding on the subjects, and it caused more than $50 \%$ of the students did not complete the study. Based on the interviews with the elementary school teachers in the coastal region, shows that in the past 10 years there is no research examining the misconception that is occurred to the students in this region. The other fact that was collected by Wahyuningsih (2015) also showed that there were students who have similar misconceptions, namely IPA misconceptions on class V of SD Canisius Beji in academic year of 2015/2016 [2]. The same study was also conducted by Wibowo (2016), who also examined the misconceptions on Natural Science in elementary school. To identify student misconceptions, we can use method 
of certainty of response index (CRI) [3]. This method was discovered by Hasan Saleem in 1999. This method is a tool used to measure respondents' confidence/assurance level in answering problems/questions that are given together with each question answer. Based on the explanation, a research on identification of misconception on Natural Science using CRI (certainty of response index) in elementary school students in Tarakan should be done in order to find the solutions and identify misconceptions that are experienced by students. The problem statements in this study are as follows: 1) How many the student percentage that have misconception on Nature Science on elementary school in Tarakan City? And 2) How is Nature Science misconception on elementary school students in Tarakan City?

\section{Nature Science Characteristics}

Nature Science is knowledge discipline that has characteristics as other disciplines. Each discipline apart from having general characteristics it also has special features/characteristics. As for general characteristic of a science is a set of facts and rules stating the relationship between each other. Those facts are systematically arranged and stated with appropriate language and certainty to make it easily searchable and understandable for communication.

On a site Stated by Pardede (2010) that the special features include (a) Natural Science has scientific value, meaning that the truth in Natural Science can be proven again by others by using scientific approaches and procedures as done earlier by the inventor; (b) The Natural Science is a collection of knowledge that is systematically arranged, and in its common usage is limited to natural phenomena; (c) Natural Science is a theoretical knowledge; (d) Natural Science is a series of related concepts; and (e) Natural Science includes four elements: product, process, application and attitude [4].

The products can be in a form of facts, principles, theories, and laws. The process is a problem solving procedure. Application is an application of the method or scientific work and the concept of Natural Science in daily life. Attitude is a curiosity to any objects, natural phenomena, living beings, as well as the causal relationship inducing new issues that can be resolved through the correct procedures.

\section{Nature Science Teaching for Elementary School}

The concept of Nature Science in elementary school is an integrated concept because it has not been separated independently like the subjects of chemistry, biology, and physics. Natural Science as a knowledge discipline and due to its application in society makes Natural Science education to be very important. In learning Natural Science should also adjusting to a child's cognitive structure. Paolo and Marten (in Samatowa, 2009) define the process skills as follows: (1) to observe, (2) to understand the observed subjects, (3) to use the new knowledge to predict what will happens, (4) to test the predictions under certain conditions to see whether the predictions are true or false [5]. In Natural Science, the students and other learners should remain skeptical to allow them always ready to modify their models about this nature to be in line with the new discoveries.

\section{Definition of misconception}

The form of misconception can be taken from any initial concept, errors, improper relationships between the concepts, intuitive ideas or naive view. Novak (in Suparno, 2013) defined the misconception as interpretation of concepts against unacceptable statement. Brown (1989; 1992) described that misconception is a naïve view and define it as an idea that is not in accordance with the scientific sense that is accepted at this moment. Feldsine (1987) considered misconception as an error and an improper relation between concepts. Fowler (1987) described it in more detail on misconception meaning. He looked misconception as an inaccurate understanding of the concept, the use of the wrong concepts, classification of wrong examples, the chaos of different concepts, and the hierarchical relationship on wrong concepts. Hasan (1997) also defined misconception as a different cognitive structure (understanding) from the existing understanding and from accepted facts in daily life, and this cognitive structures could interferes the reception to new science [6]. From the above understanding it can be concluded that the misconception is a concept that is incompatible with the scientific sense or with the understanding that being received by the experts.

\section{The causes of misconception}

Misconception may come from several sources, such as from teachers who deliver false concept, from the students, and also from the lack of proper teaching methods. According to Supano (2013), the causes for misconception happened are caused by the condition of students, teachers, textbooks, and context and teaching methods. For more details, the causes of misconceptions are as follows:

a. Student

Misconception from the students can occur because of students' association to daily terms that lead to misconceptions.

b. Teacher

Student's misconception may occur if the teacher does not master the concept that will be taught to students properly.

c. Teaching methods

Some teachers who use less accurate teaching methods, especially who emphasizes only in one side to the involved concept, although in overall it could help students to understand the subject, it could lead to misconception in student.

d. Book

The uses of too difficult and complex language sometimes make the student cannot understand well to the written subject in the book, as a result, the student misinterpret the book contents.

e. Context

In this case the specific causes of misconception are the use of daily language, friends, as well as the beliefs and religious teachings.

Suparno (2013) classified the causes of misconception as in Table 2.1 below. 


\section{JIP Fo}

TABLE I

THE CAUSE OF STUDENT'S MISCONCEPTION

\begin{tabular}{|c|c|}
\hline Main cause & Special cause \\
\hline \multirow[t]{8}{*}{ Student } & Preconception \\
\hline & Associative thinking \\
\hline & humanistic thoughts \\
\hline & Incomplete / incorrect Reasoning \\
\hline & Wrong intuition \\
\hline & $\begin{array}{l}\text { Student's cognitive development } \\
\text { stage }\end{array}$ \\
\hline & Student's ability \\
\hline & Student's interest \\
\hline \multirow[t]{4}{*}{ Teacher/lecturer } & $\begin{array}{l}\text { Did not master the subject, } \\
\text { incompetent }\end{array}$ \\
\hline & $\begin{array}{l}\text { Did not a graduate from the correct } \\
\text { department }\end{array}$ \\
\hline & $\begin{array}{l}\text { Did not allow students to express } \\
\text { their ideas }\end{array}$ \\
\hline & Teacher's bad relationship \\
\hline \multirow[t]{6}{*}{ Textbook } & Wrong explanation \\
\hline & $\begin{array}{l}\text { Wrong writing, especially in the } \\
\text { formula }\end{array}$ \\
\hline & $\begin{array}{l}\text { The writing level is too high for } \\
\text { students }\end{array}$ \\
\hline & $\begin{array}{l}\text { Students do not know how to read } \\
\text { textbooks }\end{array}$ \\
\hline & $\begin{array}{l}\text { In order to attract the readers, } \\
\text { fiction books of science sometimes } \\
\text { give deviate concept }\end{array}$ \\
\hline & $\begin{array}{l}\text { Cartoons often contain } \\
\text { misconception }\end{array}$ \\
\hline \multirow[t]{8}{*}{ Context } & Student's experience \\
\hline & Different colloquially (daily \\
\hline & language) \\
\hline & Wrong discussion friend \\
\hline & Faith and religion \\
\hline & $\begin{array}{l}\text { Wrong explanation from parents or } \\
\text { others }\end{array}$ \\
\hline & $\begin{array}{l}\text { Student's life context (wrong tv, } \\
\text { radio, film) }\end{array}$ \\
\hline & $\begin{array}{l}\text { Feeling happy / not happy free or } \\
\text { depressed }\end{array}$ \\
\hline \multirow[t]{10}{*}{ Teaching method } & Only lecturing and writing \\
\hline & Directly into mathematical form \\
\hline & $\begin{array}{l}\text { Do not express student's } \\
\text { misconception }\end{array}$ \\
\hline & Did not correct the wrong \\
\hline & homework \\
\hline & Analogy model \\
\hline & Practicum model \\
\hline & Discussion model \\
\hline & Limited demonstration model \\
\hline & Non-multiple intelligences \\
\hline
\end{tabular}

\section{Certainty of Response Index (CRI)}

Certainty of Response Index method is a method that was introduced by Hasan Saleem, Diola Bagayoko, and Ella L. Kelley to measure the emerging misconception. Using CRI method, respondents are asked to provide certainty level of their own ability by associating confidence level with knowledge, concepts, or law. CRI method asks respondents to answer questions along with the provision of degree or scale

(degree of) respondents' confidence in answering the question. This method can describe student's confidence to the correctness of the response alternatives answer.

CRI scale is modified to 4, namely: Understood, Understood with less confident, misconceptions, and Do not Know the Concept. When the confidence scale is low (CRI grades ranging at 0-2) it is stated that the respondents answer the question by guessing, regardless whether the answers are right or wrong. It also shows that the respondents do not understand the concept. When the CRI scales are high, and the answers are correct, it shows that respondents understand the concept (the answers have reasons), however if the CRI scales are high, and the answers are wrong, it shows any misconceptions are experienced. Thus, whether the students have misconceptions, or do not understand any concept, it can be distinguished in a simple way namely by comparing whether the question answers are true or not with the answer the high and low index (CRI) is given to that question. The condition to distinguish between students who know the concepts, misconceptions, and who do not understand the concept for respondents in individual and in groups can be seen in Table 2 below

TABLE II

CRI CONDITIONS FOR DISTINGUISHING STUDENT WHO KNOW CONCEPTS, MISCONCEPTIONS, AND WHO DO NOT UNDERSTOOD THE ANY CONCEPTS

\begin{tabular}{|c|c|c|}
\hline $\begin{array}{l}\text { Answer } \\
\text { Criteria }\end{array}$ & Low CRI $(<2.5)$ & High CRI (> 2.5) \\
\hline $\begin{array}{l}\text { The Answer is } \\
\text { correct }\end{array}$ & $\begin{array}{l}\text { The answer is } \\
\text { correct but the CRI } \\
\text { is low, it means that } \\
\text { the student do not } \\
\text { understand the } \\
\text { concept (lucky } \\
\text { guess) }\end{array}$ & $\begin{array}{l}\text { The answer is } \\
\text { correct and the CRI } \\
\text { is high, it means that } \\
\text { the student know the } \\
\text { concept well }\end{array}$ \\
\hline $\begin{array}{l}\text { The Answer is } \\
\text { Wrong }\end{array}$ & $\begin{array}{l}\text { The answer is } \\
\text { wrong and the CRI } \\
\text { is low, it means that } \\
\text { the student do not } \\
\text { understand the } \\
\text { concept }\end{array}$ & $\begin{array}{l}\text { The answer is wrong } \\
\text { but the CRI is high, } \\
\text { it means that } \\
\text { misconceptions are } \\
\text { happened }\end{array}$ \\
\hline
\end{tabular}

From the table 2, it can be deduced that every student data is oriented to a combination of right and wrong answers, as well as based on the intensity of CRI, then the data diagnosis are grouped into three groups of students namely the student who have understood the subject, misconceptions, and the student who do not understand. The functions of CRI methods are based on research of Saleem et.al., namely:

1. as a means to assess the appropriateness/suitability of emphasis of a concept in multiple sessions.

2. as a diagnostic means to allow teachers to modify his teaching method

3. as a means to assess the progress/effectiveness of the used teaching method.

4. as a means to compare the effectiveness of teaching methods including technologies, strategies. Did the 


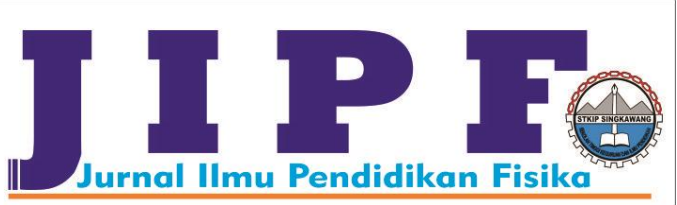

integrated approaches are able to improve student's understanding and increase student proficiency in solving problems or not.

\section{Elementary School in Tarakan City}

Elementary school (abbreviated SD; English: Elementary School) is the most basic level of formal education in Indonesia. Elementary school is completed within 6 years, ranging from $1^{\text {st }}$ grade to $6^{\text {th }}$ grade. Currently, $6^{\text {th }}$ grade students are required to participate in National Examination/Ujian Nasional (formerly is called with Ebtanas) and school examination (or called US) affecting the students' graduation. Elementary school graduates can continue their education to junior high school (or the equivalent). Elementary school can be held by the government or private party. Since the regional autonomy was applied in 2001, the management of public elementary school (SDN) in Indonesia that was previously under the Ministry of Education has been the responsibility of district/city local government now. While the Ministry of Education only acts as a regulator in terms of national education standards. In structure, the public elementary school is the technical executing unit of districts/cities education department. Tarakan City has 47 elementary schools, 1 Public Special School, and 20 private elementary schools spread around Tarakan.

\section{METHODS}

\section{A. Research design}

The research study used a quantitative descriptive research. Descriptive research is a research study that describes or represents the existing phenomena [7].

\section{B. Population and sample}

The population in this research study was students in sixth grade elementary school in Tarakan city who had receive subject on force, light and simple machines. Cluster sampling was used as sampling technique, with consideration of three school criteria, namely school with category of favorite school, medium category school, and low category based on the UAS average value of Natural Science subject, namely SDN A, SDN B Tarakan, and SDN C Tarakan.

\section{Research Instruments}

Multiple choice test instrument was used in this research study with total 40 questions and also included with CRI model answer sheets.

\section{Data collection technique}

To collect data, this study provide test using CRI response sheet. The selection of confidence level was modified simpler from 6 scales to 3 scales, namely confident, doubt and unsure.

The student's answers based on CRI criteria category were percentage based on categories of understand, misconception, and do not understand. It was calculated with formula [8]

$$
P=\frac{f}{N} \times 100 \%
$$

Jurnal Ilmu Pendidikan Fisika

Volume 2 Number 2 month September 2017. Page 54-59 p-ISSN: 2477-5959 e-ISSN: 2477-8451

Note:

$P$ : percentage figure of group

$f$ : Total students in each group

$N$ : Total individuals (the total number of students designated as research subject)

\section{E. Data analysis technique}

Data was collected from the CRI diagnostic test result. Students' answers were assessed with the following assessment criteria:

TABLE III

QUESTION ASSESSMENT CRITERIA

\begin{tabular}{ccc}
\hline Question type & Score & Description \\
\hline Multiple Choice & 1 & If the answer is correct \\
& 0 & If the is wrong answer \\
\hline
\end{tabular}

The misconceptions percentage level can be categorized into several categories as shown in Table 4 below.

TABLE IV

MISCONCEPTION CATEGORIES

\begin{tabular}{cc}
\hline Percentage & Category \\
\hline $0-30 \%$ & Low \\
$31 \%-60 \%$ & Medium \\
$61 \%-100 \%$ & High \\
\hline
\end{tabular}

\section{RESULTS AND DISCUSSION}

The students' answers are presented in four categories, namely understand the concept (PK), understand the concept with less confident (PKKY), misconceptions (M) and Do not Know concept (TTK). Student Answers of SDN A are presented in Figure 1 below.

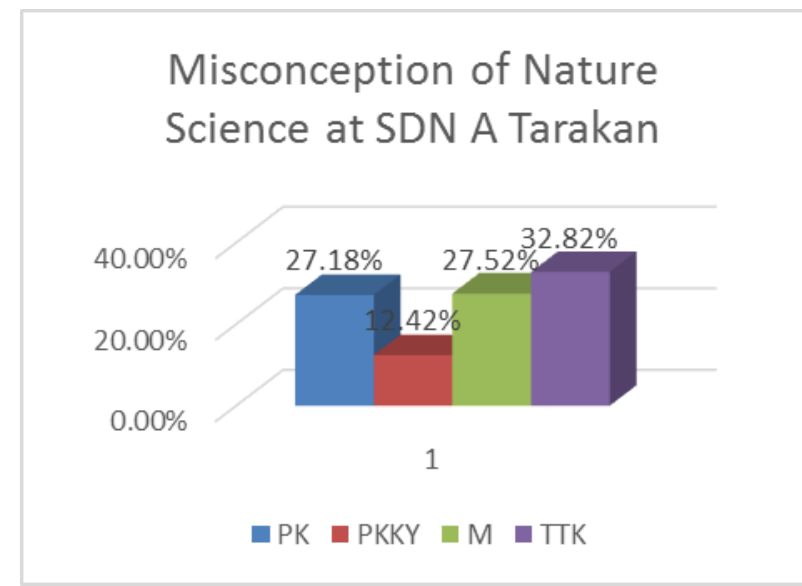

Fig. 1 Misconception of Nature Science at SDN A Tarakan

Based on Figure 1, , shows that as many as $27.18 \%$ are categorized in Understand the Concept, as many as $12.42 \%$ are categorized as student who understand the concept with less confident, and $27.52 \%$ are categorized as student who misconception, and as many as $32.82 \%$ are categorized as student who does the student who do not know the concept. 


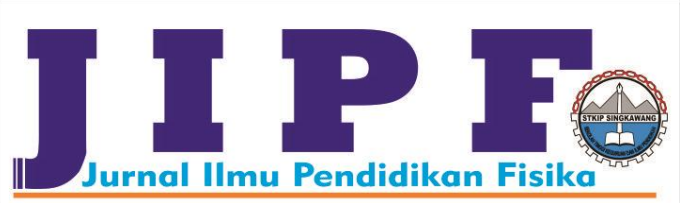

Total questions that cause misconception are more than $30 \%$ and are shown in number 2, 3, 5, 16, 19, 20, 21, 22, 25, 26, 27 and number 31 .

The data of students' answer from SDN B Tarakan are presented in Figure 2 below.

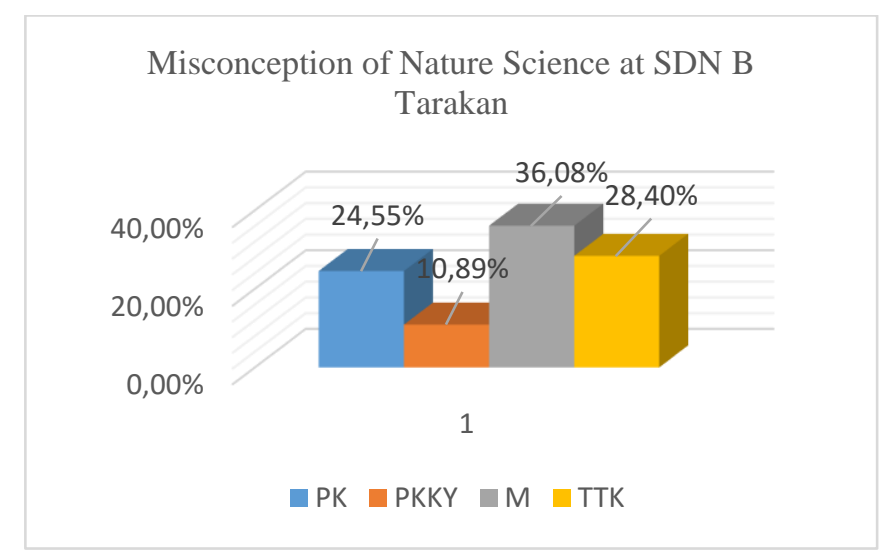

Fig. 2 Misconception of Nature Science at SDN B Tarakan

Based on Figure 2, it is shown that as many as $24.55 \%$ are categorized as the students who Understand concept, as many as $10.89 \%$ are categorized as student who understand the concept with less confident, as many as $36.08 \%$ are categorized as student who had misconception, and as many as $28.40 \%$ are categorized as student who do not know the concept. Total questions that cause misconception are more than $30 \%$ are shown in number $2,3,5,8,10,11,15,16,19,20,21,22,23$, 24, 25, 26, 37.31, 38 and 39.

The data of students' answer from SDN C Tarakan are presented in Figure 3 below.

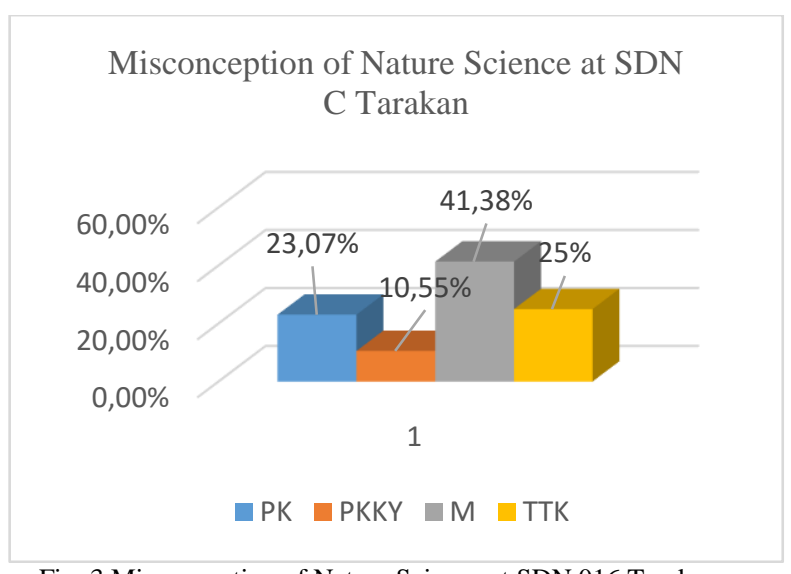

Fig. 3 Misconception of Nature Science at SDN 016 Tarakan

Based on Figure 3, it is shown that as many as $23.07 \%$ are categorized as the students who Understand concept, as many as $10.55 \%$ are categorized as student who understand the concept with less confident, as many as $41.38 \%$ are categorized as student who had misconception, and as many as $25 \%$ are categorized as student who do not know the concept. Total questions that cause misconception are more than $30 \%$ are shown in number $2,3,5,8,10,11,15,16,19,20,21,22,23$, $24,25,26,37.31,38$ and 39.
Question with highest misconception is question on number 19 with average of $75.27 \%$, the question contains image of feather and marble at the same height in vacuum tube and then the feather and marble are dropped from the same height. Student of SDN A who had misconceptions were as many as $71 \%$ students; $82.1 \%$ of students at SDN B Tarakan and $72.7 \%$ of students at SDN C Tarakan. Some students thought that the marble was the first object that arrived to the ground. Their assumption was taken from daily activities, where object with greater mass would first arrive to the ground than object with smaller mass. They did not pay attention to the condition where feather and marble were located. The other students answered that feather and marble float in the air like an astronaut who float in outer space. The fact is the absence of (or small) gravity causes the absence of air in outer space. However, the absence of air in the tube does not mean the absence of gravity because gravity is an attractive force between objects (between the feather and the earth, and between the marble and the earth). Both of these objects will fall with the same acceleration, and will get to the bottom of the tube simultaneously because of no air friction within the tube. Based on the selection of answers, the correct answer is A where both objects fall to the bottom of the tube simultaneously, i.e. marble and feather will fall on the same basis if it were in a vacuum tube.

The second highest question experiencing misconception was question number 25 with an average misconception of $68.07 \%$. As many as $51 \%$ students at SDN A Tarakan experienced misconception, $85 \%$ students at SDN B Tarakan also experienced misconception and $68.2 \%$ students at SDN C Tarakan experienced misconception also. The misconception was happened on subject where the stone was thrown in the middle of the pond where the poolside water comes from the edge of the pool. However, many students answered that the poolside water came from location where the rock fell namely in the middle of the pool and the water also came from the bottom of the pool where the rock had fallen. The students might think that the water travels along the wave. The fact is when the wave passes, the water move up and down (vibrating), therefore the correct answer is $\mathrm{C}$.

The third highest question experiencing misconception was number 21 with an average misconception of $62 \%$, a question about force to object. The first image was an image of a jockey who rode his horse, and the other image was an image of a man pushing a wall. As many as $51 \%$ students at SDN A experienced misconception; $71.4 \%$ students at SDN B Tarakan experienced misconception, and $63.6 \%$ students at SDN C Tarakan experienced misconception. Most of the students answered that the horse exerts a force to the jockey, while the wall did not exert a force to the man. They assumed that only living organisms that can exert a force, while inanimate objects could not exert any force to living organisms. The opposite was assumed by some students where only the inanimate objects that can exert force while horse could not exert force because the horse was ridden by humans.

In determining the most powerful misconseptions then be identified as a group. Analysis of misconceptions students in groups can be known based on the average value of CRI were answered correctly and the answer wrong and the fraction of 


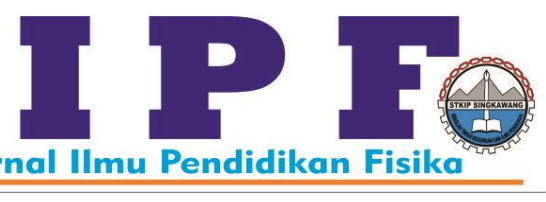

students who answered correctly. The average value of wrong CRI (CRIS) can be seen in Table 5.

TABLE V

CRIS AT SDN A,B AND C TARAKAN

\begin{tabular}{|c|c|c|c|c|}
\hline $\begin{array}{c}\text { No } \\
\text { Quetion }\end{array}$ & $\begin{array}{c}\text { CRIS } \\
\text { SDN A } \\
\text { TRK }\end{array}$ & $\begin{array}{c}\text { CRIS } \\
\text { SDN B } \\
\text { TRK }\end{array}$ & $\begin{array}{c}\text { CRIS } \\
\text { SDN C } \\
\text { TRK }\end{array}$ & $\begin{array}{c}\text { Average } \\
\text { CRIS }\end{array}$ \\
\hline 1 & 0 & 4 & 5 & 3.00 \\
\hline 2 & 3.9 & 4.1 & 4.6 & 4.20 \\
\hline 3 & 3.9 & 3.4 & 3.5 & 3.60 \\
\hline 4 & 3.1 & 3.2 & 2.2 & 2.83 \\
\hline 5 & 4 & 4 & 4.5 & 4.17 \\
\hline 6 & 2.7 & 2.4 & 3.1 & 2.73 \\
\hline 7 & 2.8 & 2.8 & 4.1 & 3.23 \\
\hline 8 & 3,03 & 3.8 & 3.71 & 3.51 \\
\hline 9 & 3.2 & 2.8 & 3.5 & 3.17 \\
\hline 10 & 3.3 & 4.6 & 4.11 & 4.00 \\
\hline 11 & 3,03 & 4.04 & 4.55 & 3.87 \\
\hline 12 & 2.8 & 3.1 & 3.72 & 3.21 \\
\hline 13 & 3.1 & 3.2 & 4.05 & 3.45 \\
\hline 14 & 3.1 & 4.2 & 3.5 & 3.60 \\
\hline 15 & 2.8 & 3.8 & 4.1 & 3.57 \\
\hline 16 & 3.1 & 3.7 & 4.7 & 3.83 \\
\hline 17 & 2.5 & 2.7 & 4.6 & 3.27 \\
\hline 18 & 2.6 & 2,95 & 3.8 & 3.12 \\
\hline 19 & 4.2 & 4.4 & 4.5 & 4.37 \\
\hline 20 & 3.9 & 3.6 & 3.6 & 3.70 \\
\hline 21 & 3.8 & 4.6 & 4.03 & 4.14 \\
\hline 22 & 3.9 & 3.5 & 3.3 & 3.57 \\
\hline 23 & 2.6 & 3.5 & 2.5 & 2.87 \\
\hline 24 & 3.3 & 3.5 & 3.4 & 3.40 \\
\hline 25 & 3.7 & 1.9 & 4.2 & 3.27 \\
\hline 26 & 3.04 & 3.8 & 4 & 3.61 \\
\hline 27 & 3.3 & 3.5 & 3.9 & 3.57 \\
\hline 28 & 3 & 2 & 4 & 3.00 \\
\hline 29 & 5 & 4.5 & 3.6 & 4.37 \\
\hline 30 & 3.5 & 4.4 & 4 & 3.97 \\
\hline 31 & 3.5 & 4.05 & 3.9 & 3.82 \\
\hline 32 & 3.1 & 2.9 & 4.1 & 3.37 \\
\hline 33 & 3.3 & 4.1 & 3.7 & 3.70 \\
\hline 34 & 3 & 2.6 & 4.4 & 3.33 \\
\hline 35 & 2.2 & 2 & 1.7 & 1.97 \\
\hline 36 & 2.8 & 5 & 3.3 & 3.70 \\
\hline 37 & 3.5 & 4.5 & 3.8 & 3.93 \\
\hline 38 & 3.3 & 3.6 & 3.4 & 3.43 \\
\hline 39 & 3.4 & 3.8 & 3.5 & 3.57 \\
\hline 40 & 2.6 & 2.1 & 2.7 & 2.47 \\
\hline
\end{tabular}

According to Table 2. The obtained results of the analysis stating that misconceptions occur if the average value of 2.5 $<$ CRISâ $\leq 5$ [6]. In diagnostic tests CRIS biggest misconception
Jurnal Ilmu Pendidikan Fisika

Volume 2 Number 2 month September 2017. Page 54-59 p-ISSN: 2477-5959 e-ISSN: 2477-8451

is No. 19 shown with an average value of CRIS 4.37, The value of CRIS show students who answered incorrectly has a very high degree of confidence in answering the questions provided. So on this concept misconception that experienced the most powerful student.

\section{CONCLUSION}

The total misconception that occur on Student SDN A Tarakan was $27.52 \%$, SDN B Tarakan experienced misconception of Nature Science as many as $36.075 \%$, and SDN C Tarakan experienced misconception of Nature Science as many as $41.38 \%$. Misconception on Nature Science that was occurred was included in subjects force and wave.

\section{REFERENCES}

[1] Susanto, Ahmad, Teori Belajar \& Pembelajaran di Sekolah Dasar, Jakarta: Kencana, 2013.

[2] Wahyuningsih, Esti, Identifikasi Miskonsepsi IPA Siswa Kelas V di SD Kanisius Beji Tahun Pelajaran 2015/2016, (Thesis,. Study Program of Elementary School Teacher of Universitas Negeri Yogyakarta; Yogyakarta, 2015.

[3] Wibowo, Ardi, Miskonsepsi IPA Fisika Siswa Kelas V SD Negeri Semester 2 Se Kecamatan Berbah Sleman Tahun 2015, (Skripsi), Study Program of Elementary School Teacher of Universitas Sanata Dharma; Yogyakarta, 2016.

[4] Pardede, Timbul. (2010). Hakikat IPA. Karakteristik IPA. [Online].

Available:http://tpardede.wikispaces.com/Unit+1.1.2+K arakteristik+IPA), accessed on September 15, 2016.

[5] Samatowa, Usman, Pembelajaran IPA di Sekolah Dasar, Jakarta: Indeks, 2011.

[6] Saleem Hasan, D. Bagayoko, and E. L. Kelley, Misconceptions and The Certainty of Response Index (CRI), Phys. Educ. 34(5), pp. 294-299, 1999.

[7] Sukmadinata, Nana, Metode Penelitian Pendidikan, Jakarta: Postgraduate Program of Universitas Pendidikan Indonesia \& Rosda, 2011.

[8] Sudijono, Anas, Pengantar Statistika Pendidikan. Jakarta: Rajawali Per, 2009.

[9] Dahuri R, Rais Y, Putra SG, Sitepu, M.J, Pengelolaan Sumber daya Wilayah Pesisir dan Lautan Secara Terpadu, Jakarta: PT. Pradnya Paramita, 2011.

[10] Tayubi, Yuyu R., Dentifikasi Miskonsepsi Pada KonsepKonsep Fisika Menggunakan Certainty Of Response Index (CRI), Mimbar Pendidikan. No. 3/XXIV/2005, 2005. 